S. I. CONCILIAR TRINITARIANISM

DOI: https://doi.org/10.14428/thl.v4i2.23773

\title{
When and How in the History of Theology Did the Triune God Replace the Father as the Only True God?
}

\author{
DALE TUGGY
}

filosofer@gmail.com

\begin{abstract}
A traditional view is that Christians have always believed that the one God is three Persons in one essence or being. Orthodox analytic theologian Beau Branson has recently argued that this is untrue, as earlier "fathers" taught that the one God just is the Father. He argues that this sensible Eastern view was misunderstood by Western sources, which is how the idea of the one God as tripersonal entered into mainstream Christian theologies. While I agree with Branson that in about the first three Christian centuries the teaching was that the one God just is the Father, I argue that his account about when and how the idea of a triune God comes in is mistaken, because we can see this new idea of a tripersonal God appearing in both Eastern and Western sources around the time of the council at Constantinople in 381, the surviving statement of which is the earliest "official" creed which assumes and implies that the one God is the Trinity, the tripersonal God.
\end{abstract}

Keywords: trinitarian, unitarian, Beau Branson, Eastern Orthodoxy, monarchy of the Father.

\section{Learning that the Catholic Narrative is False}

A trinitarian theology is one on which the unique God is the Trinity; its defining claim is that the one God is tripersonal, being or somehow containing three "Persons" in or sharing "one essence" (or "being" or "nature"). In my view the previous sentence is uncontroversially true. ${ }^{1}$ But interestingly, recently some

\footnotetext{
1 Simply consult the official statements of trinitarian groups. "God... [reveals] himself as Father, Son, and Holy Spirit... with the Father, the Son is one and the same God. ... with them [i.e. Father and Son], the Spirit is one and the same God." (Catechism of the Catholic Church, secs. 26163.); “...we believe in one God, who is one single essence, in whom there are three persons...
} 
learned Eastern Orthodox theologians have denied this. This is an argument about words, but as will become clear, it is not only about words, but about the history and the proper understanding of mainstream Christian theology. It is crucial that analytic theologians who want to be engaged with historical sources get clear on what actually happened.

It is perhaps easiest to explain our disagreement by way of autobiography. In the 2000s, sustained examination of rival Trinity theories, rival ways of understanding creedal language about "God," "Persons," and the divine "essence," combined with unwavering trust in apostolic tradition, turned me from a trinitarian into a unitarian Christian, someone who thinks that the one true God is not the Trinity but rather the Father alone. I'd begun, like so many Christian philosophers, with an interest in well-argued defensive apologetics. I assumed that the reason so many Christian or quasi- or pseudo-Christian groups rejected "the Trinity" was that they thought it to be incoherent (to imply a logical contradiction, or at least something obviously impossible). Surely, I assumed, there is a defensible way of parsing this language, steering carefully around various incoherent or otherwise theologically objectionable claims. But to my surprise, all the then-current theories, even steadfast appeal to "mystery," seemed seriously problematic in various ways. I was also learning that historically, many Protestants have been unitarian in their theology, rather than trinitarian. I learned that what so many present-day analytic philosophers uncritically assume, that "the Trinity" is clearly implied by biblical teachings, is something which has been denied by many informed, learned, and seemingly Christian people. And the arguments from the Bible to the claim that there is a triune God, I realized, were slippery and contentious, not obvious and compelling. ${ }^{2}$ To make a long story short, I discovered for myself what many biblical scholars and historians know but often don't draw much attention to: there is no idea of a triune God in the Bible.

When we exclude theologies historians call "modalistic monarchian," we find that no tripersonal god is mentioned in the first three centuries of Christian history. In the last two decades of the second century, when some Christians started to use the Greek trias and the Latin trinitas, they were plural referring

Father, Son, and Holy Spirit." ("The Belgic Confession," sec. 8.); "The eternal triune God reveals Himself to us as Father, Son, and Holy Spirit, with distinct personal attributes, but without division of nature, essence, or being." ("The Baptist Faith and Message," sec. 2.); "Thus, the Church teaches that while there is only One God, yet there are Three who are God - the Father, the Son, and the Holy Spirit... God is both One and yet Three..." (Hopko 1981); "the Lord our God who is One Lord, as a trinity or as one Being of three persons" ("Assemblies of God 16 Fundamental Truths," sec. 2a.).

2 Tuggy 2017b, chap. 10; Tuggy 2019c. 
terms, not singular referring terms. ${ }^{3}$ In contrast, in much traditional theology, and typically today, "the Trinity" is assumed to be a singular referring term, like a title or a proper name, referring to the tripersonal God. This is why it is misleading to translate trias or trinitas from sources in the second, third, and early fourth centuries as "Trinity." Initially these terms were understood to refer to a triad, namely the one God, his Logos, and his Spirit - to those three things/beings, however exactly they are related to one another. This ambiguity is still the root of much confusion; even today, some theologians habitually jump back and forth between "the Trinity" (singular referring term) meaning the one God (understood to be tripersonal) and "the Trinity" (plural referring term), meaning the Father, the Son, and the Spirit, however exactly those are related to one another. ${ }^{4}$

\section{Three Competing Narratives}

These facts which I at length learned, facts which many had learned before me, are inconsistent with what I call the catholic narrative about trinitarian theology. ${ }^{5}$ This is the story that Christians have always believed in and worshiped the Trinity (the triune God, the god in whom or in which there are three equally divine "Persons"), although it took them a few centuries of reflection to come up with language and concepts which are in some sense adequate to express this belief. I too believed this story, until I came to see a clash between New Testament theology, on which the one God is the Father alone, and later, trinitarian traditions, on which the one God is the Trinity. ${ }^{6}$ Being a Protestant, committed to God's self-revelation through his unique Son and through the apostles he trained, I was compelled to pick the first over the second. In sum, study of

${ }^{3}$ I discovered this through my own reading of primary sources, but was happy to find this judgment confirmed by a leading twentieth century patristic scholar: "Tertullian, who called the several Persons of the godhead 'God' in plain terms, also makes free use of the word trinitas. As with the early Greek theologians, trinitas bears a collective sense. It simply means triad, not triunity." (Prestige 1952, 93, italics added).

${ }^{4}$ This ambiguity is useful to them. One can say things like "The Bible is all about the Trinity" - and this is arguably true, if "the Trinity" just means God, the Son of God (or God's Logos), and the Spirit of God. And this will allow one's listener to conclude that the Bible is centrally about the triune God, even though such a thing goes unmentioned in the Bible (that is, no term or phrase in the Bible was then understood to refer to a triune God).

${ }^{5} \mathrm{I}$ call it this because it is widely shared among Protestants, Catholics, and Orthodox believers, although in recent times many Catholic scholars disagree with it based on careful, nonanachronistic readings of the earliest Christian sources, starting with the New Testament. (E.g. Küng 1996, 95-97).

${ }^{6}$ Tuggy 2019b; Tuggy 2012. 
Christian history and the Bible caused me to become more reformed and less catholic in my theology than I was before. Along the way, I also explored all sorts of logical, metaphysical, epistemic, and biblical problems for various Trinity theories. ${ }^{7}$

In a recent paper Orthodox analytic theologian Beau Branson accuses me of "a kind of logical smoke-and-mirrors, a semantic sleight-of-hand." ${ }^{8}$ What is my crime? Defining the term "trinitarian" so as to require the idea that the one God is triune/tripersonal. I have argued that when we carefully define the terms "trinitarian" and "unitarian" in well-motivated, non-polemical, descriptive ways, it turns out that the famous early apologist Tertullian is unitarian in his theology, not trinitarian. And so too a recent new Trinity theory. ${ }^{9}$ Branson finds all of this pretty outrageous, and urges that my definitions illicitly violate "the ordinary intuitions of most of us" scholars. ${ }^{10}$ Worse, my definitions would wrongly classify numerous important historical theologians. ${ }^{11}$ In place of mine, he offers his own definitions of "trinitarian" and "unitarian" - definitions which in my view are clearly inadequate for multiple reasons. But this semantic spat should be confined to its own paper; for all I say here perhaps both Branson and I are poor definers. In this paper, I will argue that history is on my side, in that the narrative that Branson tells about the history of Christian theology is false in an important respect, whereas mine is true in that same respect.

Branson and I agree that the catholic narrative is false; early Christians never mention, imply, or assume the existence of a tripersonal god. ${ }^{12}$ We agree that the concept of a tripersonal God came into mainstream Christian tradition some time in the last half of the fourth century. But we disagree about how and to what extent it entered. I have said in print that although this concept of a tripersonal god is nowhere to be found in the first ecumenical council of 325, it was assumed - though interestingly, not clearly expressed - by the second ecumenical council of $381,{ }^{13}$ which is why we very soon thereafter see theologians like Augustine

7 Tuggy 2003; Tuggy 2004; Tuggy 2013; Tuggy 2014; Tuggy 2017b.

${ }^{8}$ Branson Forthcoming, sec. 3.

9 Tuggy 2016a; Tuggy 2013; Brower and Rea 2005.

${ }^{10}$ Branson Forthcoming, sec. 4.

${ }^{11}$ Ibid., secs. 6, 9.

${ }^{12}$ For my way of arguing that the New Testament authors think the one God to be the Father alone, and so not the Trinity, see Tuggy 2019a. An earlier version of that chapter is Tuggy 2017a. A more popular presentation is my opening statement in Tuggy and Brown 2019.

${ }^{13}$ Tuggy 2017b, 90. 
saying obviously trinitarian (i.e. triune God related) things. ${ }^{14}$ I see mainstream tradition developing from a unitarian theology (the one God just is the Father) and human christology in the New Testament, to subordinationist and increasingly triadic Logos theories and the various "monarchian" negative reactions to those from about 150 on. These two continue as rival streams in the tradition right through the long post-Nicea controversy, with the subordinationist stream being more dominant, especially in the East. ${ }^{15}$ From this struggle emerges the trinitarian "solution" first assumed in an "official" source in 381. For lack of a catchier label, I'll call this the Nicene development narrative. It's compatible with plenty of East-West differences, but it's part of the story that we see the transition to the one God being the Trinity right in both Greek and Latin sources in the years shortly before and after the 381 council, and so it is not to be explained as an initially "Western" (Latin-speaking) misunderstanding.

According to Branson, both the catholic and the Nicene development narratives are mistaken. He offers in their stead what I'll call the Western misunderstanding narrative. In this story, the earliest Christians, as well as the New Testament and the important Greek "fathers" held what he calls "the Strong Monarchy View," which is that "Strictly speaking, The one God just is the Father", 16 in other words, that God and the Father are numerically identical, which would imply that this is false: that the one God just is the Trinity. ${ }^{17}$ Any account of the Trinity, or more accurately, of the triad, which includes "the Strong Monarchy View" Branson calls "Monarchical Trinitarianism."18 In Branson's view, this sort of theology is really what the framers of "the doctrine of the Trinity" had in mind, and somehow "Western" theologians like Augustine (d.

${ }^{14}$ For example, "These two we call the Father and the Son, and both, together with the Holy Spirit, are one God. ...This Trinity is one God..." (City of God 11.10) [p. 462]. "For so is the Father God, the Son God, and the Holy Spirit God, and all together are one God." (On the Trinity 15.17 [p. 200]).

15 One recent author characterizes these as "Trinitarian Theologians of Unity of Will" vs. "Trinitarian Theologians of Unity of Being." (Anatolios 2011, chap. 2) I would clarify that each side in this period is "trinitarian" only in the sense that they are trying to understand the triad, not the Trinity; calling each side "triadic" would be clearer.

${ }^{16}$ Branson Forthcoming, sec. 6. I shall focus on this piece, although Branson has posted a long video version (2018c), which I have edited, presented, and responded to in a series of podcasts starting with Tuggy 2018. Branson gives a condensed version of his views in his view in his $2018 \mathrm{~b}$.

${ }^{17}$ It is uncontroversial among those trained in modern logic that if $\mathrm{a}=\mathrm{c}$ and $\mathrm{b}=\mathrm{c}$, then also $\mathrm{a}$ $=\mathrm{b}$. Thus, if the Father just is God, and the Trinity just is God, it would follow that the Father just is the Trinity. But everyone knows this can't be true, as the Father and the Trinity are supposed to differ from one another (e.g. only the Trinity is tripersonal, only the Father eternally generates the Son). Thus, it can't be true that the Father just is God and that the Trinity just is God. At most, one of those two claims can be true.

${ }^{18}$ I shall leave aside some of Branson's other controversial neologisms. 
430), Marius Victorinus (d. c. 370), and Boethius (d. 525) misunderstood church tradition to be teaching a tripersonal God. ${ }^{19}$ In Branson's view, Eastern theology was largely if not completely free of this Western misunderstanding up through the time of Photius I (d. 893).

In order to show that "Monarchical Trinitarianism is not merely some ad hoc invention of an analytic philosopher," Branson cites five of "the world's leading contemporary Eastern Orthodox theologians" who affirm the Strong Monarchy View, ${ }^{20}$ and as far as I know Branson is right that these would deny that the one God is the Trinity and affirm instead that the one God is the Father, and that they would say that the idea that the one God is the Trinity is a serious misunderstanding of "the doctrine of the Trinity."

This is a remarkable new narrative about the idea of a tripersonal God: that it is based on a fairly late (roughly Augustine onward) misunderstanding of the true orthodox theology, as expressed in Greek sources, which is a view that excludes the one God from being the Trinity. About the triad/Trinity distinction discussed in section 1 above, Branson opines that in Greek there simply is no word or phrase that refers to the Trinity (i.e. the triune God) but only words and phrases that refer to the triad. ${ }^{21}$ In other words, what we translate as "the Trinity" or "the Holy Trinity" should never be understood as having a single referent, the triune God. As I will show below, this is false. In Greek as in Latin, in the last quarter of the fourth century a new use of "Trinity" was born, where it is a singular referring term for the only God, not a plural referring term for the "Persons" of the creeds, however those are related to one another.

${ }^{19}$ Branson Forthcoming, sec. 8.

20 Section 6. These are: John Behr, Boris Bobrinskoy, Thomas Hopko, John Meyendorff, and John Zizioulas. It's not clear to me that these are always self-consistent. I cited (footnote 1 above) Hopko, but so does Branson! (nn. 22-24.) In his earliest piece on this John Behr is unclear (1999). But in a later book, discussing Basil's theology, he says "For the Christian faith there is, unequivocally, but one God, and that is the Father. ...For Basil, the one God is not the one divine substance, or a notion of "divinity" which is ascribed to each person of the Trinity, nor is it some kind of unity or communion in which they all exist; the one God is the Father." (Behr 2004, 3078). I think he's right about Basil, but not about his famous younger colleagues, as I explain below. In a recent piece Behr clearly asserts that "there is not One God the Trinity, but One God Father Almighty, the one God, whose name is Father..." (Behr 2018, 330). See also his Behr 2008.

${ }^{21}$ Branson 2018a. 


\section{A Host of Testimonies against the Western Misunderstanding Narrative}

\subsection{Trinity vs. Triad}

In the rest of this paper I want to show that disparate and independent historical facts combine to provide strong evidence against the Western misunderstanding narrative. I shall assume that prior to the second half of the 300s there were no believers in a tripersonal god, a thesis held in common by my Nicene development narrative, the rival Western misunderstanding narrative, and interestingly many modern Roman Catholic scholars. ${ }^{22}$

A difficulty both then and now is the ambiguity of "the Trinity." The newer use of "the Trinity" as a singular referring term has never entirely replaced the older use of "the Trinity" as a plural referring term. This latter usage, referring to the Father, Son, and Spirit as to three things, doesn't assume that they are one god, but it doesn't preclude that view either. So an adherent of triune-God-free subordinationist theories like Tertullian or Origen or John Biddle or Samuel Clarke (all of whom agree with Branson and me that the one God just is the Father alone) will always (when positively employing it) use "the Trinity" as a plural referring term, ${ }^{23}$ since they think that those are in the final analysis three things/entities/beings. In contrast, a proponent of a triune God theory may use "the Trinity" that way too, but she will also, sometimes, use "the Trinity" to mean the one God, the three of them together as one god, the tripersonal god. In short, the tell-tale mark of someone who believes in the triune God is use of "the Trinity" as a singular referring term, one that can be interchanged with "God" (meaning the one God). To find believers in a triune God, then, we are looking for some term like "the Trinity" which they use to refer to the one God, understood as including the Father, Son, and Spirit. This is a sure sign of someone who believes the Father, Son, and Spirit to - somehow altogether - be the one God; they will refer to them as to a single object, a single god. ${ }^{24}$

22 Unlike Protestants, Roman Catholics do not need to claim that the biblical books teach that God is the Trinity, for they can simply admit that they do not, instead basing their trinitarian claims on the authority of Church tradition, which for them is more fundamental than that of the books of the Bible. Still, many Catholics who are not scholars and more traditional scholars accept what I call the catholic narrative about the history of trinitarian theologies.

${ }^{23}$ With the early modern unitarians Biddle and Clarke one can see the plural-referring usage right in the titles of their books (Biddle 1691; Clarke 1738).

${ }^{24}$ If I were to accept its date at face value, the earliest usages of "Trinity" as a singular referring term by a non-monarchian that I'm aware of would be in Gregory of Nazianzus's sixth oration, dated to around 364. (Gregory of Nazianzus, "Oration 6-First Oration on Peace," secs. 13, 22 


\subsection{Pre-Photius I Triune-God Statements}

If we artificially confine ourselves to "official" statements, the first clear reference to a tripersonal god I'm aware of would be in a statement produced by the fifth ecumenical council at Constantinople in 553. Its anathema against the "Three Chapters," 25 in part, sounds like the one God is supposed to be the Father, in keeping with Branson's take on "trinitarian" theology.

There is only one God the Father, from whom all things come, and one Lord, Jesus Christ, through whom all things are, and one holy Spirit, in whom all things are.

But we can't read that paragraph by itself, for it is immediately preceded by the statement that "...there is a consubstantial Trinity, one Deity [Gr: theoteta] to be adored in three subsistences or persons..."26 This Trinity, it would seem, is a god, a tripersonal god, the one to be adored by Christians. And each of the biblical one God, one Lord, and one Spirit, as many a later trinitarian would say, "is God."

A little later we see clear tripersonal-god statements from a small council at Toledo in $675^{27}$ and in the mid-700s from John of Damascus. ${ }^{28}$ But we know that in some circles the idea of a tripersonal God was current much earlier. The socalled "Faith of Damasus" (sometimes attributed to the late fourth century figures Pope Damasus or Jerome), now believed to be from the latter 400s, follows up the older one-God-one-Lord-one-Spirit confession with "We do not worship and confess three Gods, but one God who is Father and Son and Holy Spirit."29

[pp. 13, 20]). However, I think this is likely to be a false positive. We don't see this usage in Gregory or other authors until later, and we know that Gregory was a self-conscious author who edited his works for publication in his retirement, in the immediate aftermath of the "victory" of Nicene orthodoxy, 381-390. In other words, this is probably an example from the 380s, when this new usage was becoming increasingly common, not from the 360 s, when it was rare to nonexistent.

${ }^{25}$ The condemned statements were by adherents of two-natures christologies.

26 "Second Council of Constantinople-553, Anathemas against the 'Three Chapters'," sec. 1 [p. 114].

27 "We confess and believe that the holy and ineffable Trinity, Father, Son and Holy Spirit, is one God by nature, of one substance, of one nature as also of majesty and power. ...each person distinctly is fully God, and the three persons together are one God. ...This Holy Trinity, which is the one true God, is not without number; yet it is not comprised by number..." ("The Eleventh Council of Toledo-Symbol of Faith (675)," 147, 149).

${ }_{28}$ Orthodox Faith, I.8 [p. 185], II.5 [210].

29 "The 'Faith of Damasus," 11. 
We see this idea too in an undisputed work of the famous fifth century St. Patrick. ${ }^{30}$

Going yet farther back, we see this idea right after the 381 council. From the year 382 we have the "Tome" of Pope Damasus, which seems to imply that God is tripersonal. (More on this below.) If this is a Western mistake, it is clearly not confined to the case of Augustine. But since these are Western sources, they are consistent with the Western misunderstanding narrative. Of course, they're also consistent with my Nicene development narrative. We must look specifically to "Eastern" or Greek language authors to see if the Western misunderstanding narrative is true or false.

\subsection{A Hostile Witness in 383: Eunomius}

For his part, the leading non-Nicene bishop Eunomius seems to understand the new orthodoxy as involving a triune god. After effectively making all but Nicene churches illegal in 381, the ensuing social unrest made the emperor wonder if he'd been too harsh, and in 383 he called a "conference of all the heresies" at Constantinople, initially with the idea that all would be allowed to speak freely. This evolved into the idea that each heretical group should simply present its beliefs for the emperor's approval or disapproval. This meeting happened in June of 383. In the end, Theodosius simply blasted all groups but the Novatians in a further decree of July 383. ${ }^{31}$ Eunomius seems to have carefully composed the answer for his faction, and this may have also been used in missionary work by these churches. For Eunomius, the one God just is the Father. And he insists, presumably against his Nicene opponents, on the absolute simplicity and changelessness of that god:

As regards the essence of which he is one, he is not divided or separated into many, nor has he at any time become something else, or changed from being what he is, nor yet out of a single essence has he been split up into a threefold substance (for he is absolutely and altogether 'one,' remaining uniformly and invariably 'only')... he is free from change or alteration since he is uncompounded...32

In this passage he's differentiating his theology from that of his neo-Nicene rivals. Eunomius seems to think that the God of the new orthodoxy is a "threefold

\footnotetext{
${ }^{30}$ In his Confession he mentions the three Persons, then says "whom we confess and adore one God in the Trinity of holy name" (quoted in Hanson 1988, 814).

31 The Theodosian Code: Book 16, sec. XVI.5.11.

32 "Confession," 151-52.
} 
substance," in some way compounded or complex, and so not simple. The components or parts of this God presumably are the "Persons" of the Trinity. To be sure, Eunomius is a hostile witness to the orthodoxy of 383, but to his dissenting voice we can add complimentary friendly testimonies.

\subsection{Gregory of Nyssa}

But first some necessary context. Basil of Caesarea (d. 379) was the eldest and leader of the "Cappadocian fathers." Branson and Behr are correct that Basil was not an adherent of a triune God theory. As I read him, he does assume that the one God just is the Father alone. Yet he adds to this traditional view the later Nicene claim that the Father and Son and Spirit share one ousia, which Basil understood as a universal, namely divinity. ${ }^{33}$ Divinity understood as a universal is by definition the property (or properties) which is (or are) sufficient to make something a god. But then, there are three divine individuals, which is to say three gods. Basil's opponents never let him forget this unwanted tritheistic implication of his commitments. Basil ineffectively hurled back a number of replies, one of which was that there is only one divine essence, one universal divinity, in his theory. ${ }^{34}$ To this we may say, as no doubt his ancient catholic opponents did: "So what? The tritheism-monotheism dispute is not about the number of universals such as divinity, but rather about the number of gods." Basil's theology features three of them, these three things with the universal divinity - and also exactly one, the Father, since he is the only God. Basil's Nicene theology was incoherent. He died in 379 , leaving this problem unresolved. His younger protégés the two Gregories were left with this problem that their common understanding of Nicene theology seemed to imply tritheism.

As I understand them, and I confess that in some places I find Gregory of Nyssa's writing to be impenetrable, both Gregories had roughly the same solution. Yes, the "divine nature" is a universal, something held in common by each of the Three. But it also just is the one God. Thus Gregory of Nyssa says that "the word of piety knows to see some distinction of hypostases in the unity of nature" 35 - that is, I take it, in God. He thinks there are three "Persons" in some sense "in" God; he believes in a tripersonal god.

\footnotetext{
${ }^{33}$ Letter 214.

${ }^{34}$ On the Holy Spirit, 76-83; "Homily on Not Three Gods"; "Homily Against the Sabellians, the Anomoians, and the Pneumatomachians"; Letter 189.

${ }_{35}$ Catechetical Discourse 1.1 (trans. Green p. 64). This same work is translated in the NPNF second series volume 5 under the title The Great Catechism.
} 
One can only read Gregory of Nyssa's carefully composed chapter 3 of his Catechetical Discourse (a.k.a. Great Catechism) as implying that God is tripersonal. I will quote it in full. Notice his mystery-mongering at the outset; this makes no sense for someone who thinks the one God just is the Father alone. But it makes a lot of sense for someone who thinks that God is somehow only one and also somehow only three, and is struggling to make sense of what at first (and perhaps at second) look seems to involve a contradiction. He also develops Basil's rhetorical portrayal of Nicene theology as a happy medium between Jewish monotheism and Greek polytheism. Here's the entire chapter with the translator's additions in brackets $([\ldots])$ and my expository comments in curved brackets $(\{\ldots\})$.

And thus he who looks precisely into the depths of the mystery grasps in secret in [his own] soul some measure of understanding of the teaching of the knowledge of God, yet is not able to make clear in speech this unutterable depth of the mystery. How is it that the same thing \{i.e. the divine nature, God\} is both numbered and escapes numeration, is both seen separately \{i.e. the Persons can be distinguished $\}$ and apprehended in unity, is both distinguished in hypostasis and not divided in underlying subject. ${ }^{36}$ For in hypostasis the Spirit is one thing and the Word another, and another again is he fi.e. the Father\} to whom the Word and the Spirit belong. But whenever you understand the distinction in these \{i.e. that these are truly three hypostases/Persons\}, again the unity of nature does not admit partition, so that neither is the might of the monarchy split, being cut up into differing divinities \{i.e. different gods\}, nor does the discourse agree with Jewish teaching, but the truth passes through the mean of the two suppositions, casting down each of the heresies and accepting what is useful from each. For the teaching of the Jew is overturned both by the acceptance of the Word and by faith in the Spirit, while the Hellenists' polytheistic error is destroyed, the unity of nature abolishing the fantasy of multiplicity. \{In other words, the one nature implies monotheism, so the falsity of polytheism\}. And again, once more, from the Jewish supposition let the unity of the nature \{i.e. the belief in exactly one God\} remain, and from Hellenism only the distinction of hypostases, each correspondingly healing the other's impious conjecture: for just as the number of the Trinity is a healing for those in error about the one [nature], the principle of unity [is a healing] for those [whose thought is] scattered in a multitude [of gods]. ${ }^{37}$

\footnotetext{
${ }^{36}$ Translator's footnote: “Here the 'underlying subject' (toi hupokeimenoi) is the divine essence (ousia) or nature (phusis)." (p. 69 n. 40)

${ }^{37}$ Catechetical Discourse 3.1-3 (trans. Green p. 69). Another modern translation of this chapter is in Bettenson 1970, 152-3.
} 
What are the Jews correct about? The existence of exactly one God. In Gregory's theology, "the unity of the [divine] nature" just is the uniqueness of God. ${ }^{38}$ What are the Jews wrong about? How many Persons are in God; they have only the Father, but there are two others in addition to him. In contrast, the Greeks are right that there is more than one divine Person, but they are wrong about the number of gods. So the happy medium is, only one God (partially agreeing with the Jews) in whom there are three Persons (partially agreeing with the Greeks). This is an argument that Basil couldn't and didn't make, as it's a properly trinitarian (tripersonal-god-involving) argument, despite his fondness for happy-medium rhetoric. ${ }^{39}$

\subsection{Gregory of Nazianzus}

To my eye the point is even clearer in the less-philosophical speculations of his friend Gregory of Nazianzus. In his $25^{\text {th }}$ oration, given in 380, he asserts that "unity is worshipped in Trinity and Trinity in unity, both its union and its distinction miraculous." 40 He later seems to use "God" and "the Trinity" interchangeably. ${ }^{41}$ And he offers a scare-mongering and fideistic response to any worries about monotheism, one which would make little sense if he simply thought that the one God was the Father alone, but which makes sense given that he's pushing a seemingly god-counting-impaired Trinity theory. ${ }^{42}$

In his famous $31^{\text {st }}$ Oration from that same year, he gives his own retooled version of Basil's one-essence-therefore-monotheism argument.

We have one God because there is a single Godhead. Though there are three objects of belief, they derive from the single whole and have reference to it. ...To express it succinctly, the Godhead exists undivided in beings divided. ${ }^{43}$

"Godhead" here is not the modern plural referring term for the triad, but is the Greek theotes, the divine essence or nature, a universal. But Gregory is well aware of the obvious reply which dogged Basil: in the case of the essence humanity,

${ }^{38}$ See also Gregory of Nyssa, Against Eunomius 2.6 (p. 108), 2.14 (p. 130), 5.1 (p. 173).

${ }^{39} \mathrm{He}$ came close though; Basil was tending in this direction, as he makes a somewhat similar argument towards the end of what is probably his latest writing. The difference is that nothing in this argument requires the idea of a multipersonal God to make sense. ("The Exameron," 106-7)

40 “Oration 25," sec. 17.

41 "....remember, if you will, that Trinity that dwells in tents - if God can at all be said to dwell in things made by human hands..." (sec. 19).

42 Sec. 18.

43 “Oration 31," sec. 14. 
still, there are many people. So it would seem that in principle, there could be one divine essence which is present in several gods. On the face of it, urging that there is one divine essence is, by itself, no help at all in securing monotheism. ${ }^{44}$ He replies that in the case of divinity the individuals are more alike and also unchanging - seemingly irrelevant points, but by now stock replies. ${ }^{45}$

He actually doesn't need to make those replies. Recall that the Nicene confession is that Father and Son are the same ousia. And going back to Aristotle, an ousia might be a thing, e.g. a man, or a kind-essence, e.g. humanity. The assumption was that this was a fundamental ambiguity in the term ousia, and that nothing could be both. But it seems to me that for Gregory here "the single whole," the Godhead/divine nature, is both that which is common to the persons (so, a kind-essence) but is also God, the triune God (so, a thing). For him, "the Godhead" is "the thing we worship." 46 There is much polemical back and forth here with non-Nicene views. But at the end of this oration he expresses his own view more fully. "For my part... I have failed to find anything in this world with which I might compare the divine nature." 47 He confesses that he can't really properly compare "the divine nature," by which I take it he means the divine entity, the triune God, to anything in the cosmos, not even the traditional "a source, a spring, and a river," or "Sun, beam, and light." 48 This latter phenomenon doesn't fit "God" (a.k.a. the divine nature/the Trinity) because in his case there is no "composition, dispersion, and the lack of a fixed, natural stability." 49 Thus he says "'goodbye' to images and shadows," and ends his oration with a resolution to

...persuade all men to worship the Father, Son, and Holy Spirit as the single Godhead and power, because to him belong all glory, honor, and might forever and ever. Amen. ${ }^{50}$

This "him" is the triune God which is Father, Son, and Spirit. Note the use of the singular personal pronoun; this Trinity is a single thing, a single God, not a mere triad of which God is a member.

In a talk from the next year, he lauds the Three as

${ }^{44}$ This is the gist of sec. 15.

45 "Oration 31," secs. 15-16.

${ }^{46}$ Sec. 17. Compare: sec. 28.

${ }^{47}$ Sec. 31.

${ }^{48}$ Secs. 31-32.

${ }^{49}$ Sec. 33.

${ }^{50}$ Sec. 33. 
...in every respect equal... each God when considered in Himself; as the Father so the Son, and the Son so the Holy Ghost; the Three One God because Consubstantial; One God because of the Monarchia. ${ }^{51}$

That is, because the Son and Spirit eternally receive the divine essence from the Father, the three of them are one God, a tripersonal God. ${ }^{52}$ Indeed, "These Three have One common name, the Godhead." 53 Or: "the Holy Trinity." 54 Again, this divine essence is also the one God. One may well ask whether it is metaphysically possible for something to be both a universal essence which can be a property of many things and an individual entity with causal powers; but at any rate, this is Gregory's view.

In another Oration from around the same time he says,

And when I speak of God you must be illumined at once by one flash of light and by three.

In other words, the one God appears as three in one respect, but as one in another. He continues,

Three in Individualities or Hypostases, if any prefer so to call them, or persons... but One in respect of the Substance - that is, the Godhead. For they are divided without division, if I may so say; and they are united in division.

Gregory here is mystery-mongering, accentuating the seeming incoherence. He continues,

For the Godhead is one in three, and the three are one, in whom the Godhead is, or to speak more accurately, Who are the Godhead.

He then mentions the heretics Sabellius and Arius. Against them, "...what need is there heretically to fuse God together, or to cut Him up into inequality?"55 "God," that is, the Trinity, a.k.a. the Godhead (divine nature/essence/being). ${ }^{56}$ And after a bit more discussion, "There is then One God in Three, and These

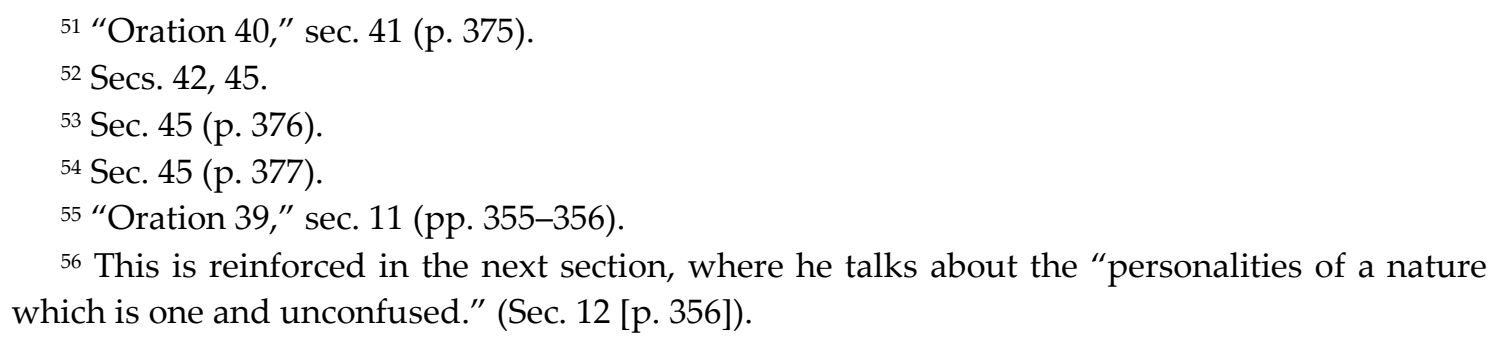

56 This is reinforced in the next section, where he talks about the "personalities of a nature which is one and unconfused." (Sec. 12 [p. 356]). 
Three are One, as we have said." 57 One what? One God, one tripersonal god, also called the "one nature."

As he resigns as second president of the 381 council, Gregory gives one last parting shot in favor of his theology. Deep into this address he offers a "concise proclamation of our teaching" for this "people which so sincerely worships the Trinity." 58

Briefly to run over its details: That which is without beginning [i.e. the Father], and is the beginning [i.e. the Son], and is with the beginning [i.e. the Spirit], is one God. ... Now, the name of that which has no beginning is "the Father," and of the Beginning "the Son," and of that which is with the Beginning, "the Holy Ghost," and the three have one Nature - God. ${ }^{59}$

This, we are assured, is "the royal road which lies between the two extremes" of Sabellianism and Arianism. ${ }^{60}$ This passage is as clearly trinitarian (i.e. concerned with a tripersonal god) as any historical theology I've read. Towards the end Gregory describes this Trinity as a single recipient of worship, ${ }^{61}$ and addresses the Trinity saying, "Farewell, O Trinity, my meditation, and my glory. Mayest Thou be preserved by those who are here, and preserve them..." 62

57 "Oration 39," sec. 12 [p. 356]. A reader for this journal objects that I've unfairly omitted a passage where Gregory identifies the one God with the Father. At the start of section 12 he quotes Paul on the one God and the one Lord (1 Corinthians 8:6) and supplements it with "and One Holy Ghost, in whom are all things..." (Ibid.) In my view, Gregory is simply preserving older language here which doesn't fit his Trinity theory, namely the habit of calling the Father "the one God." If his view really was that the one God is numerically identical to the Father alone, saying this would be his simple and compelling answer to objections that his views entail polytheism or tritheism. But see, e.g. his convoluted actual attempt at an answer them in his "Oration 20," sections 6-7. The core of it is: "It is our duty then to maintain the oneness of God and to confess three individual entities, or Persons, each with his distinctive property. The oneness of God [i.e. the Father, Son, and Spirit counting as one god] would, in my view, be maintained if both Son and Spirit are causally related to him [i.e. to the Father] alone without being merged or fused into him and if they all share one and the same divine movement and purpose, if I may so phrase it, and are identical in essence." (Sections 6-7 [p. 111]).

58 "Oration 42," sec. 15 (p. 390).

${ }^{59}$ Ibid.

${ }^{60}$ Secs. 15-16 (pp. 390-391).

${ }^{61}$ Sec. 25 (p. 394).

${ }^{62}$ Sec. 27 (p. 394). 


\subsection{Why no Explicit Tripersonal God in the 381 Creed?}

One would think that Gregory, a leader of the Nicene faction, understood the gist of that council's theology, as understood in 381. Why then do the surviving statements from that meeting not explicitly say that the one God is the Trinity?

In the popular imagination a tripersonal god doctrine was defended or established by the 325 council at Nicea. But it is uncontroversial, in light of recent scholarship, that the idea of a triune god simply was not at issue in the controversy surrounding Arius and his bishop Alexander, nor is any such idea mentioned or assumed in the 325 creed. As the 381 creed claims to be a restatement of the 325 creed (although it is uncontroversial that in some ways it is a significant revision of it), it is natural to think that neither does this 381 creed contain a tripersonal god doctrine. And a cursory glance at the council's surviving documents seems to confirm that.

But the fourth-century context explains why we don't find what we expect to find there. The terminological innovations of the 325 Nicene creed had only thrown fuel on the fire ignited by Arius and his bishop. The dispute turned out to be protracted and bitter, and various attempts were made to replace its new language with less controversial statements. This creed-making became tiresome and vexing to all sides. As Hanson notes,

We can find plenty of pro-Nicene writers in the second half of the fourth century expressing weariness with creeds and a desire to be satisfied with [the Nicene creed of 325].63

The framers of the 381 creed were so conservative that they did not even dare to say that the Holy Spirit too was homoousion with the Father, even though this was their view. ${ }^{64}$ This is also why they spun their innovative creed as a mere reaffirmation of the 325 creed; having rallied around that innovation, they did not want to be seen as introducing further innovations, leading to more agonies.

In sum, the lack of explicit tripersonal god talk in this creed is not surprising, and is not evidence against the interpretation that for those pro-Nicene bishops in 381, the shared divine ousia was assumed to entail that the three of them are one God, and so the falsity of the Father alone being the one true God. We've seen the complaint of one against whom this council acted (Eunomius), heard from a leading bishop there who was for a time president of the meeting (Gregory

\footnotetext{
${ }^{63}$ Hanson 1988, 819.

64 It was clearly the view of Basil and the two Gregories, as well as of the council at Constantinople in 382 which may have been a re-convening of the 381 meeting. (Hanson 1988, $811 ; 818-19 ; 822-23)$.
} 
of Nazianzus), and from an ally of his who was at the meeting ${ }^{65}$ and may have been influential in its deliberations (Gregory of Nyssa). And we've seen these latter two employ the idea of a tripersonal God both before and after that famous if mysterious meeting. ${ }^{66}$ These outsider and insider witnesses give us strong reason to deny the Western misunderstanding narrative.

\subsection{Theodosius and Damasus}

Another witness is the emperor who "settled" this longstanding dispute by taking and enforcing the Nicene side. He let both sides know which would be the winner and which would be the loser under his regime in his decree of February 28, 380:

It is Our will that all the peoples who are ruled by the moderation of Our Clemency shall practice that religion which the Divine Peter the Apostle transmitted to the Romans, as the religion which he introduced makes clear even now. This religion, it is evident, is followed by the Pontiff Damasus and by Peter, Bishop of Alexandria, a man of apostolic sanctity; that is to say that, according to apostolic teaching and evangelic doctrine, we shall believe in the one Deity of the Father, the Son, and the Holy Spirit, under the concept of equal majesty and of the Holy Trinity.

We command those who observe this law to assume the name of Catholic Christians. The rest, however, whom we adjudge demented and insane, shall sustain the infamy of heretical dogmas, their meeting places shall not be called churches, and they shall be smitten primarily by Divine Vengeance and secondly by the punishment of Our Power, which We have received by Divine favor.

Given on the third day before the Kalends of March at Thessalonica in the year of the fifth Consulship of Gratian Augustus and the first Consulship of Theodosius Augustus. February 28, 38067

Notice that the emperor specifies the only allowed and true doctrine in two ways: he describes it and he also refers to it as the theology taught by Pope Damasus and the Alexandrian bishop Peter II (d. 381). The description is consistent with

65 Hanson 1988, 717.

${ }^{66}$ It is mysterious because it seems that a long "tome" it produced has been lost, and because over all we know very little about what happened there. Also, scholars have wondered why we hear so little about the meeting until Chalcedon in 451, but in my view Hanson explains this relative quiet $(1988,812-20)$.

67 The Theodosian Code: Book 16, sec. XVI.1.2. 
belief in a triune God, here called "the Holy Trinity." However, it could also be read merely as asserting the late Nicene claim that each of the Three has the divine essence. The question though, is whether a background assumption at this point is that their sharing that essence entails their being one god, a tripersonal god. Let us see if the emperor's references clarify matters.

Damasus had sent delegates to the 381 council, so presumably he was reasonably informed about the theology promulgated there. In 382 he convened a council in Rome to reaffirm neo-Nicene theology and to condemn its rivals. They composed a document which we call the "Tome of Damasus," which was sent to a follow-up meeting in Constantinople in 382. While it focuses on the claim that the Three are equally divine, it also seems to assume belief in a tripersonal god:

If anyone, while saying that the Father is God, that his Son is God and that the Holy Spirit is God, divides them and means [several] gods, and does not say that they are God on account of the one Godhead and might which we believe and know to belong to the Father and the Son and the Holy Spirit; and if he excludes the Son and the Holy Spirit and believes that only the Father is God and this is what he means when he believes in one God, he is a heretic on all these points and indeed a Jew. ... because of their one and equal divinity it is not the name of "gods" but of "God" which we are shown and taught to believe... ${ }^{68}$

\section{Conclusion}

Thinking as historically-informed analytic theologians, we must reject Branson's new Western misunderstanding narrative about the origin of belief in a tripersonal God. Contrary to that narrative, we see this idea in a number of independent sources, both Eastern and Western, around the time of the second ecumenical council. Referring to that council, which was exclusively Eastern and so not really "ecumenical", ${ }^{69}$ the late R.P.C. Hanson observed that

The bishops of the Eastern Church had reached a consensus about the Christian doctrine of God. The bishops of the Western Church could find no compelling reason to disagree..$^{70}$

\footnotetext{
${ }^{68}$ Damasus of Rome, “Tome of Damasus," sec. 24 (p. 146), quotation marks added.

${ }^{69}$ Davis 1983, 119.

${ }^{70}$ Hanson 1988, 823.
} 
This vague and troublesome idea of God as Trinity, which the average Christian is afraid to think much about and about the meaning of which the experts still disagree, ${ }^{71}$ was actually born in the East. And contrary to the recent Eastern Orthodox scholars Branson cites, ${ }^{72}$ it seems to me that probably most Orthodox scholars in recent times are committed to that tripersonal God idea. Timothy Ware, a.k.a. [Orthodox] Bishop Kallistos of Diokleia, author of a popular introduction to Orthodox tradition, writes:

...God is not simply a single person confined within his own being, but a Trinity of three persons... Orthodox agree in their doctrine of God with the overwhelming majority of all who call themselves Christians. NonChalcedonians and Lutherans, members of the Church of the East and Roman Catholics, Calvinists, Anglicans, and Orthodox: all alike worship One God in Three Persons... ${ }^{73}$

His is hardly a lone voice. Learned Orthodox priest John Anthony McGuckin celebrates "the triunity of God",74 and Russian Protopresbyter Michael Pomazansky writes that

God is one in essence, but triple in Person. In other words, God is a Tri-unity, is Tri-hypostatical, is a Trinity One in Essence. ...the Three Persons are contained in the very Unity of God's Essence. ${ }^{75}$

Similarly, Orthodox theologian Vladimir Lossky writes of "personal diversity in God," and says that "God is Trinity" and that "considered together the Three are God."76

In light of the sources Branson cites, ${ }^{77}$ it would seem that Orthodox theologians need to have a good argument about what the Orthodox position is, or rather should be.

71 See the clashing theories discussed in Baber 2015, Howard-Snyder 2015, and Tuggy $2016 \mathrm{~b}$. It is unfortunate that so many recent theologians soft-pedal substantial disagreements among trinitarian theologians as mere differences of emphasis or as reflecting "different starting points."

72 See footnote 20 above.

73 Ware 1997, 209-10.

${ }_{74}$ McGuckin 2014, 71.

75 Pomazanski 1997, 73; 75. Also, he accepts the catholic narrative: "The truth of the Holy Trinity has been confessed by the Church of Christ in all of its fullness and completeness from the very beginning." (78).

${ }^{76}$ Lossky 2003, 170; 173. See also Lossky 1976, chap. 3.

77 See note 20 above. 
It is easier to refute a historical narrative than it is to establish the truth of one. I believe we have strong grounds to reject both the catholic narrative that Christians always believed in a tripersonal God and Branson's new Western misunderstanding narrative. As to my rival Nicene development narrative, here I've left it in a very threadbare, rough-sketch form. It needs much more detail to make sense and to illuminate what we find in historical authors. On the face of it, it is surprising that mainstream Christian tradition changed from thinking that the one God is the Father alone to the sort of view where the one God is the Trinity. Such a change is so surprising that many wish to deny that it happened. But it did happen, and in a relatively short period of time, with imperial assistance, and soon thereafter it was considered a non-negotiable, and moreover something which had always been clearly taught in scripture. Thus, the bishop Augustine, who was converted in 386, just after the crucial council of 381, seems to think that mainstream Christianity has always taught the triune God. ${ }^{78}$ The history of mainstream Christian theology would be so much simpler were that so! A true account of its development, one incorporating all we now know about early theologies, will be more complicated than either the catholic or the Western misunderstanding narratives.

\section{Bibliography}

“Assemblies of God 16 Fundamental Truths." 2019. https://ag.org/Beliefs/Statement-of-Fundamental-Truths\#2.

"Second Council of Constantinople-553, Anathemas against the 'Three Chapters.'" 1990. In Decrees of the Ecumenical Councils, edited by N. Tanner, 1:114-22. Washington, D.C.: Georgetown University Press.

"The 'Faith of Damasus.'" 2001. In The Christian Faith in the Doctrinal Documents of the Catholic Church, 7th ed., edited by Jacques Dupuis, 10-12. Bangalore, India: St. Peter's Seminary. http://newadvent.org/fathers/27025.htm.

“The Baptist Faith and Message." 2000. http://www.sbc.net/bfm/default.asp.

“The Belgic Confession." 1988. In Ecumenical Creeds and Reformed Confessions, 78120. Grand Rapids, Michigan: CRC Publications.

78 "The purpose of all the Catholic commentators I have been able to read on the divine books of both testaments, who have written before me on the trinity which God is, has been to teach that according to the scriptures Father and Son and Holy Spirit in the inseparable equality of one substance present a divine unity; and therefore there are not three gods but one God..." (The Trinity I.2.7 [p. 69]). 
“The Eleventh Council of Toledo-Symbol of Faith (675)." 2001. In The Christian Faith in the Doctrinal Documents of the Catholic Church, 7th ed., edited by Jacques Dupuis,146-51. Bangalore, India: St. Peter's Seminary.

“The Theodosian Code: Book 16." 1976. Edited and translated by Clyde Pharr. Nashville, Tennessee: Vanderbilt University.

Anatolios, Khaled. 2011. Retrieving Nicea: The Development and Meaning of Trinitarian Doctrine. Grand Rapids. Grand Rapids, Michigan: Baker Academic. Augustine of Hippo. 1991. The Trinity [De Trinitate]. Translated by Edmund Hill. New York: New City Press.

Augustine of Hippo. 1998. Augustine: The City of God against the Pagans [De Civitate Dei]. Translated by R.W. Dyson. Cambridge: Cambridge University Press.

Augustine of Hippo. 2002. On the Trinity Books 8-15. Translated by Gareth Matthews. New York: Cambridge University Press.

Baber, Harriet. 2015. "The Trinity." In Internet Encyclopedia of Philosophy. http://www.iep.utm.edu/trinity/.

Basil of Caesarea. 1893. "The Hexameron." In Basil: Letters and Select Works, edited by Philip Schaff and Henry Wallace, translated by Blomfield Jackson, Nicene and Post-Nicene Fathers, Second Series 8: 51-107. Edinburgh. http://www.ccel.org/ccel/schaff/npnf208.viii.i.html.

Basil of Caesarea. 1894. Letter 189. In Basil: Letters and Select Works, edited by Philip Schaff and Henry Wallace, translated by Blomfield Jackson, Nicene and Post-Nicene Fathers, Second Series 8: 228-32. Edinburgh.

Basil of Caesarea. 1973. Letter 214. In The Later Christian Fathers: A Selection from the Writings of the Fathers from St. Cyril of Jerusalem to St. Leo the Great, translated by Henry Bettenson. Oxford: Oxford University Press.

Basil of Caesarea. 2011. On the Holy Spirit. Translated by Stephen M. Hildebrand. Yonkers, New York: St Vladimir's Seminary Press.

Basil of Caesarea. 2012. "Homily Against the Sabellians, the Anomoians, and the Pneumatomachians." In On Christian Doctrine and Practice, translated by Mark DelCogliano, 277-303. Yonkers, New York: St Vladimir's Seminary Press.

Basil of Caesarea. 2012. "Homily on Not Three Gods." In On Christian Doctrine and Practice, translated by Mark DelCogliano, 259-76. Yonkers, New York: St Vladimir's Seminary Press.

Behr, John. 1999. "The Trinity: Scripture and the Greek Fathers." The Living Pulpit, April-June: 22-23.

Behr, John. 2004. The Nicene Faith. Vol. 2. The Formation of Christian Theology. Crestwood, New York: St. Vladimir's Seminary Press. 
Behr, John. 2008. "Calling Upon God as Father: Augustine and the Legacy of Nicea." In Orthodox Readings of Augustine, edited by Aristotle Papanikolaou and George E. Demacopoulos, 153-65. Crestwood, New York: St. Vladimir's Seminary Press.

Behr, John. 2018. "“One God Father Almighty.'” Modern Theology 34, 3: 320-30. https://doi.org/10.1111/moth.12419.

Bettenson, Henry. 1970. The Later Christian Fathers: A Selection from the Writings of the Fathers from St. Cyril of Jerusalem to St. Leo the Great. London: Oxford University Press.

Biddle, J. 1961. A Confession of Faith Touching the Holy Trinity; According to the Scripture. In The Faith of One God, edited by T. Firmin. London.

Branson, Beau. 2018a. "Monarchy of the Father Presentation with Narration Part 2," $\quad$ https://www.beaubranson.com/wpcontent/uploads/2018/07/Monarchy-of-the-Father-Presentation-with-

Narration-Part-2.pptx.

Branson, Beau. 2018b. One God the Father, or One God the Trinity? An Eastern Orthodox Perspective on the Monarchy of the Father and the Philosophy of the Trinity. Brescia University. https://www.beaubranson.com/monarchyofthefather/.

Branson, Beau. 2018c. The Neglected Monarchy of the Father and the Analytic Debate about the Trinity, 2018c. https://www.beaubranson.com/monarchyofthefather/.

Branson, Beau. Forthcoming. "The Neglected Doctrine of the Monarchy of the Father, and Its Implications for the Analytic Debate about the Trinity." In Analytic Theology and the Tri-Personal God, edited by O. Riaudel \& A. Perez. Leuven: Peeters.

Brower, Jeffrey E., and Michael C. Rea. 2005. "Material Constitution and the Trinity." Faith and Philosophy 22, 1: 57-76. https://doi.org/10.5840/faithphil200522134.

Catechism of the Catholic Church. Mahwah, New Jersey: Paulist Press.

Clarke, Samuel. 1738. The Scripture Doctrine of the Trinity. Wherein Every Text in the New Testament Relating to That Doctrine is Distinctly Considered; and the Divinity of Our Blessed Saviour, According to the Scriptures, Proved and Explained [4th ed.], in The Works of Samuel Clarke, D. D., Late Rector of St. James's Westminster; in Four Volumes., Vol. 4., edited by J. Clarke. London.

Damasus of Rome. 2001. "Tome of Damasus." In The Christian Faith in the Doctrinal Documents of the Catholic Church, edited by Jacques Dupuis, translated by J. Neuner, 7th ed., 144-46. Bangalore, India: St. Peter's Seminary. http://newadvent.org/fathers/27025.htm.

Davis, Leo Donald. 1983. The First Seven Ecumenical Councils (325-787): Their History and Theology. Collegeville, Minnesota: The Liturgical Press. 
Eunomius of Cyzicus. 1987. "The Confession of Faith." In Eunomius: Extant Works, translated by Richard Paul Vaggione, 149-61. New York: Oxford University Press.

Gregory of Nazianzus. 1893. “Oration 39-Oration on the Holy Lights.” In Cyril of Jerusalem, Gregory Nazianzen, edited by Philip Schaff and Henry Wallace, translated by Charles Gordon Browne and James Edward Swallow, Nicene and Post-Nicene Fathers, Second Series 7:352-59. Edinburgh.

Gregory of Nazianzus. 1893. "Oration 40-The Oration on Holy Baptism." In Cyril of Jerusalem, Gregory Nazianzen, edited by Philip Schaff and Henry Wallace, translated by Charles Gordon Browne and James Edward Swallow. Nicene and Post-Nicene Fathers, Second Series 7:360-77. Edinburgh.

Gregory of Nazianzus. 1893. "Oration 42-The Last Farewell." In Cyril of Jerusalem, Gregory Nazianzen, edited by Philip Schaff and Henry Wallace, translated by Charles Gordon Browne and James Edward Swallow. Nicene and Post-Nicene Fathers, Second Series 7:385-95. Edinburgh.

Gregory of Nazianzus. 2002. "Oration 31 [The Fifth Theological Oration]." In Saint Gregory of Nazianzus: On God and Christ-The Five Theological Orations and Two Letters to Cledonius, translated by Lionel Wickham. Crestwood, New York: St Vladimir's Seminary Press.

Gregory of Nazianzus. 2003. “Oration 20." In St. Gregory of Nazianzus: Select Orations, translated by Martha Vinson, 107-16. Washington, D.C.: The Catholic University of America Press.

Gregory of Nazianzus. 2003. “Oration 25." In St. Gregory of Nazianzus: Select Orations, translated by Martha Vinson, 157-74. Washington, D.C.: The Catholic University of America Press.

Gregory of Nazianzus. 2003. "Oration 6-First Oration on Peace." In St. Gregory of Nazianzus: Select Orations, translated by Martha Vinson, 3-20. Washington, D.C.: The Catholic University of America Press.

Gregory of Nyssa. 1892. The Great Catechism [=Address on Religious Instruction, Catechetical Discourse]. In Gregory of Nyssa: Dogmatic Treatises, edited by Philip Schaff and Henry Wallace, translated by William Moore and Henry A. Wilson, Nicene and Post-Nicene Fathers, Second Series 5:471-509. Edinburgh. http://www.ccel.org/ccel/schaff/npnf205.html.

Gregory of Nyssa. 1893. Against Eunomius. In Gregory of Nyssa: Dogmatic Treatises, edited by Philip Schaff and Henry Wallace, translated by William Moore and Henry A. Wilson. Nicene and Post-Nicene Fathers, Second Series 5:33-249. Edinburgh.

Gregory of Nyssa. 1954. Address on Religious Instruction [= The Great Catechism, Catechetical Discourse]. In Christology of the Later Fathers, edited by Edward R. 
Hardy and Cyril R. Richardson, translated by Cyril R. Richardson, 269-325. Philadelphia: The Westminster Press.

Gregory of Nyssa. 2019. Catechetical Discourse: A Handbook for Catechists [=The Great Catechism, Address on Religious Instruction], edited and translated by Ignatius Green. Yonkers: St. Vladimir's Seminary Press.

Hanson, R.P.C. 1988. The Search for the Christian Doctrine of God. Edinburgh: T\&T Clark.

Hopko, Thomas. 1981. The Orthodox Faith: Volume I-Doctrine and Scripture-The Holy Trinity - Wrong Doctrines of the Trinity. Orthodox Church in America. https://www.oca.org/orthodoxy/the-orthodox-faith/doctrine-scripture/theholy-trinity/wrong-doctrines-of-the-trinity.

Howard-Snyder, Daniel. 2015. "Trinity." In Routledge Encyclopedia of Philosophy Online, 2015. http://www.faculty.wwu.edu/howardd/Trinity.pdf.

John of Damascus. 1958. An Exact Exposition of the Orthodox Faith. In St. John of Damascus: Writings, translated by Fredoric H. Chase, The Fathers of the Church: A New Translation 37:165-408. Washington, D.C.: The Catholic University of America Press.

Küng, Hans. 1996. Christianity: Essence, History, Future. New York: Continuum. https://trinities.org/blog/hans-kung-on-new-testament-theology/.

Lossky, Vladimir. 1976. The Mystical Theology of the Eastern Church. Crestwood, New York: St. Vladimir's Seminary Press.

Lossky, Vladimir. 2003. "The Procession of the Holy Spirit in Orthodox Trinitarian Theology." In Eastern Orthodox Theology: A Contemporary Reader, Second Edition, edited by D. Clendenin 163-82. Grand Rapids, Michigan: Baker Academic.

McGuckin, John Anthony. 2014. "The Holy Trinity as the Dynamic of the World's Salvation in the Greek Fathers." In The Holy Trinity in the Life of the Church, edited by Khaled Anatolio: 65-77. Holy Cross Studies in Patristic Theology and History. Grand Rapids, Michigan: Baker Academic.

Pomazansky, Michael. 1997. Orthodox Dogmatic Theology. Translated by Seraphim Rose. Platina, California: Saint Herman of Alaska Brotherhood.

Prestige, G. L. 1952. God in Patristic Thought. 2nd ed. SPCK: London.

Tuggy, Dale, and Michael Brown. 2019. Debate-Dr. Dale Tuggy vs. Dr. Michael Brown. https://www.youtube.com/watch?v=Oi300 FvFz0.

Tuggy, Dale. 2003. “The Unfinished Business of Trinitarian Theorizing.” Religious Studies 39: 165-83. https://doi.org/10.1017/S0034412503006437.

Tuggy, Dale. 2004. "Divine deception, identity, and Social Trinitarianism." Religious Studies 40: 269-87. https://doi.org/10.1017/S003441250400705X. 
Tuggy, Dale. 2012. "How Trinity Theories Conflict with the New Testament." https://rinities.org/blog/how-trinity-theories-conflict-with-the-newtestament/.

Tuggy, Dale. 2013. “Constitution Trinitarianism: An Appraisal." Philosophy and Theology 25, 1: 129-62. https://doi.org/10.5840/philtheol20132517.

Tuggy, Dale. 2014. "Divine Deception and Monotheism." Journal of Analytic Theology 2: 186-209. https://doi.org/10.24204/ejpr.v8i3.1693.

Tuggy, Dale. 2016a. "Tertullian the Unitarian." European Journal for Philosophy of Religion 8, 3: 179-99. https://doi.org/10.24204/ejpr.v8i3.1693.

Tuggy, Dale. 2016b. “Trinity.” In The Stanford Encyclopedia of Philosophy, edited by Edward N. Zalta. http://plato.stanford.edu/entries/trinity/.

Tuggy, Dale. 2017a. "The Unfinished Business of the Reformation." Mp3. Trinities Podcast 189. https://trinities.org/blog/podcast-189-the-unfinishedbusiness-of-the-reformation/.

Tuggy, Dale. 2017b. What Is the Trinity? Thinking about the Father, Son, and Holy Spirit. Kindle Direct Publishing. http://what-is-the-trinity.com.

Tuggy, Dale. 2018. "Dr. Beau Branson on the Monarchy of the Father - Part 1." Mp3. Trinities Podcast 239. https://trinities.org/blog/podcast-239-dr-beaubranson-on-the-monarchy-of-the-father-part-1/.

Tuggy, Dale. 2019a. "The Unfinished Business of the Reformation." In Herausforderungen Und Modifikationen Des Klassischen Theismus, edited by Thomas Marschler and Thomas Schärtl, 199-227. Münster: Aschendorff Verlag.

Tuggy, Dale. 2019b. "How Trinity Theories Conflict with the Bible." Mp3. Trinities Podcast 248. https://trinities.org/blog/podcast-248-how-trinitytheories-conflict-with-the-bible/.

Tuggy, Dale. 2019c. "How to Argue That the Bible Is Trinitarian." Mp3. Trinities Podcast 260. https://trinities.org/blog/podcast-260-how-to-argue-that-thebible-is-trinitarian/.

Ware, Timothy. 1997. The Orthodox Church. New Edition. London: Penguin Books.

Published Online: April 05, 2020 